\title{
Appendix
}

\section{Regulatory Bodies in Main Jurisdictions*}

\author{
Australia \\ Australia Prudential Regulation Authority (APRA) \\ Australian Securities and Investment Commission (ASIC)
}

\section{Belgium}

Financial Services and Markets Authority (FSMA)

National Bank of Belgium (NBB)

\section{Canada}

Office of the Superintendent of Financial Institutions (OSFI)

\section{Cayman Islands}

Monetary Regulatory and Advisory Body of the Cayman Islands (CIMA)

\section{China}

China Banking Regulatory Commission (CBRC)

China Insurance Regulatory Commission (CIRC)

China Securities Regulatory Commission (CSRC)

\section{Denmark}

Financial Supervisory Authority (Finanstitsynet)

\section{France}

Autorite' des marches financiers (AMF)

\footnotetext{
*For fuller treatment of the issue of single vs multipeak regulatory structures in various jurisdictions, vide Fabri, D. (2006). A single unified supervisory authority for financial services in Malta and beyond: Some legal and regulatory issues. In Id-Dritt (pp. 251-280). Malta: UoM Law Students Society; and Engen, T., \& Lim, B. K. (2015). After market crash China mulls single super regulator. Times of Malta, November 18.
} 
90 Appendix

\section{Germany}

Federal Financial Supervisory Authority (BAFIN)

\section{India}

Forward Market Commission (FMC)

Insurance Regulatory and Development Authority of India (IRDA)

Ministry of Corporate Affairs (MCA)

Pension Fund Regulatory and Development Authority (PFRDA)

Reserve Bank of India (RBI)

Securities and Exchange Board of India (SEBI)

\section{Ireland}

Central Bank of Ireland (CBI)

Dublin Financial Services Authority (DFSA)

\section{Italy}

Commissione Nazionale per le Societa' e le Borse (CONSOB)

Institute for the Supervision of Insurance (IVASS)

\section{Japan}

Financial Services Agency (FSA)

\section{Luxembourg}

Commissariat aux Assurance (CAA)

Commission de Surveillance du Secteur Financiere (CSSF)

\section{New Zealand}

Financial Markets Authority (FMA)

\section{Norway}

Financial Supervisory Authority of Norway (Finanstitsynet)

\section{Portugal}

Portuguese Insurance Regulator (ASF)

Portuguese Securities Market Commission (CMVM) 


\section{Russia}

Central Bank of Russia

\section{Singapore}

Monetary Authority of Singapore (MAS)

\section{South Africa}

Financial Services Board

National Credit Regulator

South African Reserve Board

\section{Spain}

Banco de Espana (Banking Sector Regulator)

Direction General de Seguros (DGS)

Spanish Securities Market Commission

\section{Sweden}

Financial Services Authority (Finansinspektionem)

\section{Switzerland}

Swiss Financial Market Supervisory Authority (FINMA)

Swiss National Bank

Six Swiss Exchange

\section{United Kingdom}

Bank of England (BoE)

Financial Conduct Authority (FCA)

Prudential Regulation Authority (PRA)

\section{USA}

Vide Fig. 1.2. 